\title{
ANALISIS MAKNA LAGU SAZANKA (KAJIAN SEMIOTIKA)
}

\author{
Z. Rahman ${ }^{1}$, M.S.M. Al Hakim², K.W.P. Kartika ${ }^{3}$ \\ ${ }^{123}$ Jurusan Pendidikan Bahasa Jepang, Universitas Pendidikan Ganesha, Singaraja \\ e-mail: zaifur2000@gmail.com, syahrulmuharram99@gmail.com, wirakartika77@gmail.com
}

\begin{abstract}
Abstrak
Penelitian ini bertujuan untuk membahas tentang analisis makna pada lirik lagu sazanka dengan subyek penelitian adalah peneliti sendiri. Dengan objek penelitian adalah lirik lagu band Sekai No Owari yang berjudul sazanka. Metode yang digunakan dalam pengumpulan data pada penelitian ini adalah metode analisis wacana/observasi dan diskusi terfokus dengan sumber data lirik lagu sazanka. Data dianalisis dengan pendekatan semiotik deskriptif kualitatif, yang menghasilkan data berupa kalimat atau kata yang terdapat pada lirik lagu Sazanka. Hasil dari penelitian ini adalah, (1) makna lirik Sekai No Owari berjudul sasanka adalah mengenai seorang kakak yang mengerti tentang keadaan adiknya sejak awal menghadapi berbagai rintangan, kakak tersebut menemaninya serta meberikan motivasi terhadapnya hingga ia sukses.
\end{abstract}

Kata kunci: Sazanka, semiotik, makna

要旨

この研究は、研究者自身が研究者であるササンカの歌詞の意味の分析について議論することを目的と

しています。研究の目的は、バンドの世界の終わり、サザンカと題された歌詞です。この研究のデ

一タ収集で使用される方法は、談話分析/観察の方法であり、サザンカ歌の歌詞データのソースとの集 中的な議論です。データは定性的な記述記号論的アプローチで分析され、サザンカの歌詞に含まれる 文章または単語の形式でデータが生成されました。この研究の結果は次のとおりです。（1）世界の 終わりの歌詞「サザンカ」の歌詞の意味は、最初からさまざまな障害に直面している弟の状態を理解 し、成功するまで弟に同行し、やる気を与えた兄に関するものです。

キーワード : サザンカ、記号論、意味

\section{Pendahuluan}

Lagu merupakan salah satu karya yang dapat dinikmati sebagai media hiburan, serta dapat juga dikaji menjadi sebuah penelitian. Karena lagu mempunyai banyak makna yang terkandung didalam setiap lirik yang ada. Makna tersebut dapat dikaji dengan teori semiotika yaitu di bidang tanda. Salah satu teori semiotika yang menggunakan tanda adalah teori Pierce yaitu teori segitiga tanda dalam memaknai sesuatu. Dalam penelitian ini akan menggunakan teori segitiga Pierce untuk mengkaji sebuah makna lagu jepang yang berjudul sazanka. Dengan menggunakan teori segitiga ikon, indeks, dan simbol dari teori tersebut. Lagu sazanka cukup menarik untuk di teliti karena memiliki makna tersirat yang disampaikan keada pendegar yang dapat diteliti melalui ikon, indeks, dan symbol.

Rumusan masalah dalam penelitian ini adalah sebagai berikut: Apa makna Ikon, Indeks, dan Simbol dalam lagu sazanka dan Apa makna yang terkandung dalam lagu sazanka.

\section{Semiotik}

Semiotika bersala dari bahasa yunani yaitu Semion yang berarti tanda atau Sign dalam bahasa inggris. Semiotik adalah bidang ilmu yang mengkaji berbagai struktur tanda serta proses terjadinya tanda dalam sebuah objek penelitian. Tokoh yang terkenal dalam dalam semiotik yakni Ferdinand de Saussure seorang linguistik dari Swiss dan Charles Sander Peirce seorang ahli filsafat dari Amerika. Teori Pierce menggunakan segitiga makna dalam menemukan makna dalam sebuah objek penelitian.

\section{Teori Trikotomi Peirce (Ikon, Indeks, dan Simbol)}

Trikotomi mengklasifikasikan tanda berdasarkan hubungan antara representamen dan objek. tiga anggota trikotomi ini adalah Ikon, indeks dan symbol adalah sebuah objek 
yang menjadi sebuah acuan untuk menemukan tanda yang nantinya tanda tersebut akan digunakan untuk memaknai sebuah objek penelitian, seperti: makna lagu sazanka yang diteliti sekarang.

a. Ikon adalah tanda yang menyerupai benda yang mewakilinya. Hubungan antara tanda dan petandanya yang bersifat bersamaan dan alamiah dengan kata lain tanda dan objek sifatnya mirip. Memiliki ciri-ciri sama dengan yang dimaksud, contoh ikon seperti : peta dengan potret gambar. Adalah benda yang memiliki ciri-ciri sama. Suatu benda yang dapat dilihat dan disentuh. Pada umumnya bersifat sama suatu gambaran dapat menampakkan bagian bumi atau bidang datar menggunakan skala tertentu.

b. Indeks adalah tanda yang mengikuti makna denotasi dan memiliki ciri-ciri mempunyai hubungan sebab akibat, jadi suatu tanda dapat dikatakan indeks jika tanda dan petandanya berhubungan, contoh dari indeks seperti : ada asap yang ditimbulkan oleh api. Mempunyai hubungan sebab akibat. Yang berarti adanya asap berarti mendakan adanya api.

c. Simbol adalah suatu tanda, yang hubungan tanda dan denotasinya memiliki ikatan yang konvensional, tanda tanpa kemiripan maupun kaitan. Tanda yang dirancang untuk menyandingkan sumber acuan melalui kesepakatan bersama, simbol tertentu yang ada dalam sebuah objek penelitian. Misalnya : warna putih yang berarti suci. Secara umum pemahaman seseorang akan warna putih adalah menandakan kesucian.

\section{Metode}

Metode penelitian adalah cara pemecahan masalah penelitian. Yang dilaksanakan secara teliti/cermat dan terstruktur dengan maksud agar tujuan yang ingin dicapai tercapai dengan sempurna serta memahami maksuda dari apa yang akan diteliti. Metode yang digunakan pada penelitian ini adalah metode kualitatif deskriptif. Adapun data yang di gunakan adalah lirik lagu jepang yang berjudul Sazanka yang inti dari lagu tersebut mengenai bagaimana usaha keras dari seseorang yang jatuh bangun untuk meraih impiannya yang ditemani oleh seorang kakak yang selalu memberikan dukungan ketika ia akan mulai menyerah atau putus asa. Metode kualitatif deskriptif digunakan karena sumber data akan di peroleh dari lirik lagu yang nantinya akan di deskripsikan temuan-temuannya. Tidak diperoleh dari prosesur statistik atau bentuk hitungan lainnya.

\section{Hasil dan Pembahasan}

Data Sazanka

\begin{tabular}{|l|l|}
\hline Lirik & Arti \\
\hline ドアの閉まる音 カレンダーの印 & $\begin{array}{l}\text { Suara pintu yang tertutup; penanda } \\
\text { di kalender }\end{array}$ \\
\hline 部屋から聞こえる 君の泣き声 & $\begin{array}{l}\text { Kudengar suara tangismu di dalam } \\
\text { kamar }\end{array}$ \\
\hline 逃げる事の方が怖いと君は夢を追い続けてきた & $\begin{array}{l}\text { Kau yang terus mengejar mimpi } \\
\text { karena takut akan melarikan diri }\end{array}$ \\
\hline 努カが報われず 不安になって & $\begin{array}{l}\text { "Bagaimana kalau kerja keras saja } \\
\text { tidak cukup?” }\end{array}$ \\
\hline 珍しく僕に当たったりして & $\begin{array}{l}\text { Tidak biasanya kau mengeluh } \\
\text { padaku }\end{array}$ \\
\hline
\end{tabular}




\begin{tabular}{|c|c|}
\hline ここで諦めたら今までの自分が可哀想だと & $\begin{array}{l}\text { "Kalau aku menyerah di sini, kasihan } \\
\text { 'aku' yang sudah sampai di sini," }\end{array}$ \\
\hline 君は泣いた & Tangismu \\
\hline 夢を追う君へ & Padamu yang mengejar mimpi \\
\hline 思い出して つまずいたなら & Ingatlah, kalau kau tersandung, \\
\hline いつだって物語の主人公は笑われる方だ & $\begin{array}{l}\text { Bahwa dalam pikiranku, tokoh utama } \\
\text { cerita apa pun selalu adalah yang } \\
\text { ditertawakan }\end{array}$ \\
\hline 人を笑う方じゃないと僕は思うんだよ & $\begin{array}{l}\text { Bukan yang menertawakan orang } \\
\text { lain }\end{array}$ \\
\hline 誰よりも転んで＼cjkstart誰よりも泣いて & $\begin{array}{l}\text { Jatuh lebih keras dari siapa pun, } \\
\text { mengangis lebih pilu dari siapa pun, }\end{array}$ \\
\hline 誰よりも君は＼cjkstart立ち上がってきた & $\begin{array}{l}\text { Lebih dari siapa pun, kau tegak } \\
\text { berdiri lagi }\end{array}$ \\
\hline 僕は知ってるよ & Aku tau \\
\hline 誰よりも君が一番輝いてる瞬間を & $\begin{array}{l}\text { Saat di mana kau bersinar paling } \\
\text { terang, lebih dari siapa pun }\end{array}$ \\
\hline 夢を追う君へ & Padamu yang mengejar mimpi \\
\hline 思い出して くじけそうなら & $\begin{array}{l}\text { Ingatlah, ketika kau merasa akan } \\
\text { hancur, }\end{array}$ \\
\hline いつだって物語の主人公が立ち上がる限り & Cerita apa pun akan terus berlanjut \\
\hline
\end{tabular}




\begin{tabular}{|c|c|}
\hline 物語は続くんだ & $\begin{array}{l}\text { Selama tokoh utamanya belum } \\
\text { menyerah untuk kembali berdiri }\end{array}$ \\
\hline 嬉しいのに涙が溢れるのは & $\begin{array}{l}\text { Air mata yang tertumpah dalam } \\
\text { bahagia ini }\end{array}$ \\
\hline 君が歩んできた道のりを知っているから & $\begin{array}{l}\text { Adalah karena aku tau jalan yang } \\
\text { kau tempuh untuk sampai di sini }\end{array}$ \\
\hline 夢を追う君へ & Padamu yang mengejar mimpi \\
\hline 思い出して つまずいたなら & Ingatlah, ketika kau tersandung, \\
\hline いつだって物語の主人公は笑われる方だ & $\begin{array}{l}\text { Tokoh utama cerita apa pun selalu } \\
\text { adalah yang ditertawakan }\end{array}$ \\
\hline 人を笑う方じゃない & $\begin{array}{l}\text { Bukan yang menertawakan orang } \\
\text { lain }\end{array}$ \\
\hline 君ならきっと & Pasti begitu adamu \\
\hline
\end{tabular}

Lirik lagu Sazanka terdiri dari 26 bait, pada lirik lagu di atas terjadi pengulangan kata pada bait yaitu”夢を追う君へ” sebanyak 3 kali, “思い出して つまずいたなら” sebanyak 2 kali, dan “いつだって物語の主人公は笑われる方だ” sebanyak 2 kali.

1. Trikotomi Peirce

Trikotomi kedua adalah icon, index, dan symbol. Icon adalah sebagai tanda yang ada sedemikian rupa sebagai kemungkinan, tanpa tergantung adanya sebuah denotatum. Denotatum adalah objek yang menjadi acuan tanda. Objek dalam lagu ini adalah カレンダーの印 (penanda di kalender).

a. Ikon

Ikon pada lagu Sazanka adalah kalender. Lagu sazanka menceritakan tentang orang-orang yang mengejar mimpi dan orang yang mengawasi mereka. Hal ini sesuai dengan lirik lagu 逃げる事の方が怖いと君は夢を追い続けてきた yang menandakan seseorang yang sedang meraih mimpi, dikarenakan pada lirik 逃げる事 の方が怖いと君は夢を追い続けてきた yang berarti seseorang sedang berusaha meraih mimpi. Oleh karena itu, ikon dari usaha adalah カレンダーの印 tanda di kalender. 
b. Indeks

\begin{tabular}{|c|c|c|}
\hline No & $\begin{array}{l}\text { Lirik } \\
\end{array}$ & Makna \\
\hline 1 & $\begin{array}{l}\text { 夢を追う君へ思い出して つまずいたなら } \\
\text { Yume wo ou kimi e. Omoidashite } \\
\text { tsumazuita nara } \\
\text { Untukmu yang mengejar mimpi. Ingatlah } \\
\text { ketika kau terjatuh }\end{array}$ & $\begin{array}{l}\text { Sang adik yang } \\
\text { memberikan semangat } \\
\text { dan nasihat kepada } \\
\text { kakaknya yang ingin } \\
\text { mengejar mimpi bahwa } \\
\text { akan banyak ada } \\
\text { rintangan }\end{array}$ \\
\hline 2 & $\begin{array}{l}\text { いつだって物語の主人公は笑われる方だ } \\
\text { Itsudatte monogatari no shujinkou wa } \\
\text { warawareru hou da } \\
\text { Sampai kapanpun protagonis di dalam } \\
\text { cerita adalah pihak yang ditertawakan }\end{array}$ & $\begin{array}{l}\text { Sang adik percaya } \\
\text { bahwa kakak nya } \\
\text { bagaikan seorang } \\
\text { protagonis yang harus } \\
\text { menerima banyak } \\
\text { rintangan dan } \\
\text { ditertawakan oleh orang } \\
\text { lain jika ingin berusaha } \\
\text { untuk mencapai } \\
\text { mimpinya. }\end{array}$ \\
\hline 3 & $\begin{array}{l}\text { 人を笑う方じゃないと㒒は思うんだよ } \\
\text { Hito wo warau hou janai to boku wa omoun } \\
\text { da yo } \\
\text { Bukan seperti senyum orang lain, itulah } \\
\text { yang kupikirkan }\end{array}$ & $\begin{array}{l}\text { Sang adik berfikir bahwa } \\
\text { kakak nya bukanlah } \\
\text { orang yang akan } \\
\text { menertawakan orang lain } \\
\text { karena kakaknya orang } \\
\text { yang sudah berusaha } \\
\text { keras dalam mencapai } \\
\text { cita-cita }\end{array}$ \\
\hline
\end{tabular}

\section{c. Simbol}

Simbol yang ada pada lagu Sazanka adalah sebuah usaha yang keras. Saat berjuang meraih mimpi salah satu benda sebagai pengingat hari penting yang akan terjadi adalah kalender. Karena sesuai dengan denotanumnya maka penanda di kalender yang membuktikan sebuah usaha yang telah dan akan dilakukan. Jadi ikatan konvesional yang timbul adalah kesan usaha yang dilakukan.

\section{Simpulan dan Saran}

Simpulan yang didapat dari analisis data adlah lirik lagu Sazanka memiliki denotatum penanda di kalender. Hal ini dikarenakan kalender sebagai bukti seorang yang pernah berjuang untuk meraih mimpi. Kata sazanka dapat diartikan bunga kamelia. Lagu sazanka menceritakan seorang yang sedang berusaha untuk meraih mimpi dan seseorang yang mendukungnya. Bagaikan seorang tokoh utama dalam sebuah cerita yang selalu berdiri disaat yang sulit maka cerita akan terus berlanjut.

\section{Daftar Pustaka}

Shelpalonewalker, 06 Juni 2018. Sekai No Owari サザンカ (Sazanka). https://kaoruyukina.wordpress.com/2018/06/06/sekai-no-owari-sazanka/. Diakses pada tanggal 20 juni 2020.

Site default, 18 mei 2017. Teori semiotika charles sander pierce-sign-object-interpretant. https://pakarkomunikasi.com/teori-semiotika-charles-sanders-pierce. Diakses pada tanggal 19 juni 2020. 
Jurnal Ayumu 2 september 2017 makna lirik lagu tradisional amefuri. https://ejournal.unitomo.ac.id/index.php/ayumi/article/viewFile/395/321. Diakses pada tanggal 18 juni 2020.

Suryotomo, D. (2015, Agustus 09). Proposal Penelitian STUDI SEMIOTIKA. Retrieved Maret 23, 2020, from academia: https://www.academia.edu/14597017/Proposal Penelitian STUDI SEMIOTIKA

wordpress. (2017, Desember 12). Metode Penelitian Kuantitatif. Retrieved Maret 23, 2020, from sosiologis.com: http://sosiologis.com/metode-penelitian-kuantitatif 